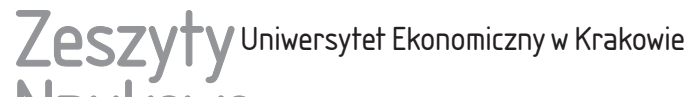 Naukowe
}

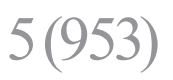

ISSN 1898-6447

Zesz. Nauk. UEK, 2016; 5 (953): 125-129

DOI: 10.15678/ZNUEK.2016.0953.0508

Piotr Rubaj

\section{Recenzja książki Arthura R. Kroebera pt. „China's Economy: What Everyone Needs to Know"}

Polityczne i gospodarcze zmiany, jakie zostały zapoczątkowane w Chinach w latach 80. XX w., doprowadziły do wielu wewnętrznych reform w tym kraju i wywarły ogromny wpływ na gospodarkę światową. Po śmierci Mao rozpoczął się proces przechodzenia Chin od gospodarki centralnie planowanej do autorytarnego systemu gospodarki wolnorynkowej związanej z decentralizacją władzy i stopniową prywatyzacją majątku narodowego oraz otwarciem rynku wewnętrznego dla inwestorów zagranicznych. Przemiany te spowodowały rozpad systemu komunistycznego i przebudowę całej chińskiej gospodarki. Wprowadzone wtedy reformy polegające na stopniowym uwalnianiu różnych sektorów gospodarki spod kontroli państwa sprawiły, że kraj ten zaczął rozwijać się nadzwyczaj dynamicznie, a jego ogromny potencjał demograficzny i gospodarczy przyniósł szybki wzrost wartości PKB, napływ bezpośrednich inwestycji zagranicznych, powstanie silnego rynku kapitałowego, wzrost popytu wewnętrznego oraz rozwój międzynarodowych powiązań handlowych.

W XXI w. Chiny wkroczyły jako jeden z najszybciej rozwijających się rynków wschodzących z dwucyfrową dynamiką wzrostu gospodarczego, stale umacniającą się pozycją w handlu międzynarodowym oraz walutą narodową ze światowymi aspiracjami. Rynek wewnętrzny tego kraju, z racji jego demograficznego potencjału oraz konsekwentnego wzrostu dochodów indywidualnych, stał się jednym z najatrakcyjniejszych na świecie dla eksporterów i inwestorów z różnych krajów.

Publikacją odnoszącą się do tematyki współczesnej gospodarki Chin jest monografia autorstwa Arthura R. Kroebera zatytułowana China's Economy: What Everyone Needs

Piotr Rubaj, Katolicki Uniwersytet Lubelski Jana Pawła II, Katedra Międzynarodowych Stosunków Gospodarczych, 20-950 Lublin, Al. Racławickie 14, e-mail: piotr.rubaj@kul.lublin.pl

1 Reformy zostały zapoczątkowane po śmierci Mao Zedonga, który zmarł 9 września 1976 r., kiedy władzę przejął Deng Xiaoping i zainicjował pierwsze w tym kraju reformy oraz stopniowe otwieranie się Chin na kontakt ze światem zewnętrznym. 
to Know (Gospodarka chińska. Wszystko, co każdy powinien wiedzieć na jej temat), wydana nakładem wydawnictwa Oxford University Press w USA (New York 2016, s. 318). Autor już we wprowadzeniu do tej pracy podkreśla, że jej głównym celem jest prezentacja współczesnej roli Chin w gospodarce światowej oraz próba określenia pozycji, jaką ten kraj będzie zajmował w kolejnych latach, a także kierunków jego ewolucji i rozwoju. Monografia skierowana jest zarówno do odbiorców zawodowo zaangażowanych w problemy gospodarcze i społeczne, jak i tych, którzy poszukują odpowiedzi na kluczowe pytania dotyczące zasad funkcjonowania współczesnej gospodarki światowej. Autor określa ekonomię jako dyscyplinę wiedzy przypominającą bardzo skomplikowany organizm, w którym zachodzące różne procesy są wzajemnie powiązane lub, używając innej metafory, jest to trójwymiarowa układanka, w której poszczególne elementy stale się przemieszczają, co znacząco utrudnia jej uporządkowanie. Chiny i ich gospodarka są tak właśnie postrzegane i tym samym wymykają się prostym opisom, ocenom i schematom. To kraj z wielowiekową tradycją, doświadczeniami w dziedzinie sprawowania władzy, zhierarchizowanym społeczeństwem oraz współcześnie z aspiracjami do roli światowego mocarstwa.

Recenzowana książka zawiera wprowadzenie, trzynaście rozdziałów oraz dodatek obejmujący aneks statystyczny i literaturę uzupełniającą. Pomimo braku podziału na sekcje można dopatrzeć się pewnej metodologii w porządkowaniu informacji o gospodarce chińskiej, polegającej na tym, że rozdziały zawierają logiczną i chronologiczną kolejność prezentowanych procesów i zdarzeń. W pewnym uproszczeniu kolejność tę można przedstawić następująco: rozdział pierwszy odnosi się do realizacji przez Chiny określonej polityki ekonomicznej i ma wymiar częściowo historyczny, w rozdziałach od drugiego do piątego autor scharakteryzował strukturę gospodarki, a następnie przedstawił system finansowy, środowisko naturalne, procesy demograficzne, strukturę rynku wewnętrznego oraz realizowany w tym kraju gospodarczy model wzrostu. Podsumowanie zawiera informacje dotyczące pozycji Chin w gospodarce światowej. Taki układ informacji pozwala czytelnikowi prześledzić najważniejsze wydarzenia w gospodarce chińskiej, jakie miały miejsce w ostatnich trzech dekadach transformacji politycznej i ekonomicznej, a także zapoznać się ze strukturą i specyfiką gospodarki chińskiej.

Odnosząc się bardziej szczegółowo do informacji zawartych w poszczególnych rozdziałach można zauważyć, że w pierwszym z nich zamieszczonych jest wiele informacji, porównań gospodarczych, faktów historycznych oraz odniesień do sytuacji w regionie i na świecie. Autor przedstawia specyfikę i realia chińskiego, autorytarnego systemu społeczno-gospodarczego, dalece różniącego się od tych w demokratycznych krajach wysoko rozwiniętych, ale również mającego zupełnie inną specyfikę niż typowe systemy totalitarne. Kreśli jego odmienność, udane i chybione reformy, zmiany rynkowe pod kontrolą partii komunistycznej oraz przeobrażenia strukturalne zacofanej gospodarki. Niewątpliwie to tylko wybrane aspekty chińskiej ,rewolucji gospodarczej”, która zapoczątkowana została pod koniec lat 70. ubiegłego stulecia, po śmierci Mao Zedonga, a następnie była kontynuowana przez Deng Xiaopinga, który zapoczątkował rzeczywiste reformy polityczne i gospodarcze.

W drugim rozdziale autor w przejrzysty sposób kreśli istotę i przebieg najważniejszych dla rozwoju kraju przeobrażeń w rolnictwie, które jak podkreśla, miały duży 
wpływ na wszystkie dziedziny życia głównie dlatego, że zainicjowały proces prywatyzacji całej gospodarki. Zwraca on także uwagę, że jeszcze pod koniec lat 70. ubiegłego wieku udział sektora rolnego w strukturze PKB stanowił $37 \%$, zaś obecnie stanowi tylko $9 \%$. Świadczy to o intensywnym rozwoju gospodarki chińskiej podczas ponad trzech dekad, kiedy to z zacofanego pod względem agrarnym kraju Chiny stały się najbardziej dynamicznie rozwijającą się gospodarkę na świecie, w niektórych latach z dwucyfrową dynamiką wzrostu gospodarczego. Procesy agrarne, w opinii autora, nie zostały zakończone i nadal jest sporo problemów dotyczących stosunków własności i przekształceń prywatyzacyjnych.

Rozdziały trzeci, czwarty i piąty zawierają omówienie problemów związanych z rozwojem przemysłu, procesami urbanizacji i tworzenia infrastruktury oraz kształtowania się powiązań gospodarczych w biznesie. W krótkiej recenzji bardzo trudno jest wybrać najistotniejsze fakty i procesy ze względu na obszerność omawianych zagadnień. Wydaje się jednak, że niektóre kwestie są szczególnie istotne. Udział Chin w światowym eksporcie na początku okresu transformacji w latach 80 . XX w. wynosił około $1 \%$, zaś znaczenie tego kraju w globalnej produkcji przemysłowej było marginalne. W 2014 r. udział ten wzrósł do $12 \%$, a w dziedzinie przemysłu Chiny stały się największą potęgą na świecie. Autor zadaje pytanie, jak była możliwa tak szybka transformacja i tak spektakularny sukces gospodarczy, i stara się na nie odpowiedzieć, wskazując, że rozwój ekonomiczny i skuteczne reformy strukturalne możliwe były dzięki czterem kluczowym czynnikom: powiązaniom z innymi dynamicznie rozwijającymi się gospodarkami krajów azjatyckich, takich jak: Tajwan, Korea Południowa i Japonia, sąsiedztwu Hongkongu, który ze względu na swoje bliskie związki ze światem zachodnim stał się dla Chin bezpiecznym łącznikiem ze światem i źródłem napływu bezpośrednich inwestycji zagranicznych, rozwojowi światowej sieci logistycznej, w tym przede wszystkim morskiego transportu kontenerowego, który umożliwił efektywną dystrybucję chińskich produktów przemysłowych na cały świat, oraz transferowi wiedzy technologicznej z Tajwanu, który umożliwił cywilizacyjny skok w rozwoju gospodarczym i społecznym.

Kolejne rozdziały dotyczą równie ważnych aspektów chińskiego procesu transformacji, a mianowicie zasad funkcjonowania systemu finansowego, kwestii energetycznych i ekologicznych, problemów demograficznych, rynku pracy oraz rynku wewnętrznego. Prezentowane procesy i reformy odnoszą się m.in. do systemu bankowego, który zawsze odgrywał główną rolę w finasowaniu rozwoju chińskiej gospodarki i zmieniał się, począwszy od instrumentalnego systemu dystrybucji pieniądza w pierwszych latach przekształceń, poprzez efektywne zaangażowanie się w proces kredytowania wzrostu gospodarczego, aż do bardziej aktywnej polityki inwestycyjnej na rynkach kapitałowych. Autor zwraca uwagę, że finansowanie gospodarki Chin pochodzi głównie z systemu bankowego, co odróżnia je od krajów zachodnich, w których głównym źródłem pozyskania funduszy są rynki kapitałowe. Ważne zagadnienia poruszane w odniesieniu do kwestii finansowych dotyczą polityki stóp procentowanych, wartości juana oraz próby wzmocnienia jego pozycji w dążeniu do tego, aby stał się jedną z walut światowych.

Należy zwrócić szczególną uwagę na poruszone aktualne problemy związane z zapotrzebowaniem Chin na energię elektryczną, które stanowi prawie jedną czwartą światowych potrzeb. Tak duże zużycie energii - o ponad 30\% większe niż w Stanach 
Zjednoczonych i dwukrotnie większe niż w krajach Unii Europejskiej - wiąże się z wykorzystaniem zasobów naturalnych niezbędnych do jej produkcji, a tym samym odnosi się do kwestii ekologicznych ważnych nie tylko dla samych Chin, ale również dla całego świata.

Kolejne istotne zagadnienia, które porusza autor, dotyczą problemów społecznych, w tym przede wszystkim kwestii demograficznych oraz procesów zachodzących na rynku pracy. Rozważa on, jaki wpływ na strukturę i liczbę ludności wywarła prowadzona od lat 80. ubiegłego stulecia tzw. polityka jednego dziecka, jakie są konsekwencje migracji ludności wiejskiej do dużych miast, jak będzie się kształtowała struktura wiekowa społeczeństwa w najbliższych dekadach i jakie to będzie miało konsekwencje dla systemu emerytalnego. Zagadnienia te mają podstawowe znaczenie dla rozwoju rynku wewnętrznego, generowanego przez niego popytu na towary i usługi, ale również będą miały wpływ na przyszłe wydatki socjalne.

Dwa ostatnie rozdziały, odnoszące się odpowiednio do współczesnego modelu społeczno-ekonomicznego gospodarki Chin oraz miejsca i roli, jaką ten kraj odgrywa w gospodarce światowej, stanowią podsumowanie rozważań. Niewątpliwym wyzwaniem dla Chin, jak podkreśla autor, jest proces przechodzenia od gospodarki opartej na zasobach naturalnych oraz taniej sile roboczej do takiej, w której główną rolę odgrywają sektory związane z wykorzystywaniem nowoczesnej wiedzy i technologii. Tak zdefiniowane cele i kierunki reform mają zapewnić stabilny rozwój gospodarczy Chinom oraz trwałą pozycję lidera w gospodarce światowej w przyszłości. A.R. Kroeber zwraca jednak uwagę, że nie potencjał gospodarki tego kraju, który w ciągu kilku najbliższych lat będzie największy na świecie, wywrze wpływ na całą gospodarkę światową, ale kierunki zmian politycznych i społecznych.

Obecnie kłopoty gospodarcze Chin mogą wywierać wpływ na gospodarki całego świata. Wydarzenia ostatnich miesięcy, takie jak: przewidywany spadek dynamiki wzrostu gospodarczego chińskiej gospodarki, wyraźne pogorszenie sytuacji na rynkach kapitałowych i duża niestabilność indeksów giełdowych, najgorsze od kilku lat wyniki handlu zagranicznego, spadający poziom rezerw banku centralnego, gorsze oceny w międzynarodowych ratingach i rankingach, wreszcie pesymistyczne nastroje inwestorów konsekwentnie destabilizują globalne rynki. A.R. Kroeber odnosi się do tych problemów, prezentując jednocześnie informacje w sposób przejrzysty, udokumentowany statystycznie i merytorycznie.

Literatura dotycząca przedstawionych zagadnień jest bardzo obszerna i dotyczy różnych aspektów funkcjonowania Państwa Środka. Z tego zakresu można polecić pozycje, takie jak: Social Economy in China and the World, red. N. Pun, B.H.B. Ku, H. Yan, A. Koo, Routledge, New York 2016; China's Economy. A Collection of Surveys, red. I. Claus, L. Oxley, John Wiley \& Sons, Hoboken 2015; F. Cai, Demystifing China's Economy Development, Springer, Berlin-Heidelberg 2015 oraz L. Yueh, The Economy of China, Edward Elgar Publishing Ltd, Cheltenham 2012. Pomimo takiej różnorodności dostępnych publikacji recenzowana książka ma wiele istotnych zalet, a mianowicie: po pierwsze - aktualne informacje, po drugie - bogate tło historyczne opisywanych procesów, po trzecie - liczne odniesienia do międzynarodowych powiązań, po czwarte - bogatą dokumentację statystyczną potwierdzającą prawdziwość prezentowanych wnio- 
sków oraz klarowny język, bardzo przystępny nawet dla czytelnika nieposiadającego wykształcenia ekonomicznego. Omawiana publikacja, pomimo że jest typową publikacją ekonomiczną, może być również przydatna dla osób poszukujących odpowiedzi na pytania dotyczące problemów współczesnego świata, w tym również roli Chin w zmieniającej się rzeczywistości.

\section{Review of Arthur R. Kroeber's "China's Economy: What Everyone Needs to Know"}

(Abstract)

The process of political and economic reform in China was initiated just after the death of the leader of the Chinese Communist Party, Mao Zedong, in 1976. Understanding past and current reality of this country is difficult as its economic and political system is somewhere between a bureaucratic and authoritarian one-party state and a market-orientated modern economy. Over the last three decades, China has joined the ranks of world leaders in the political, economic and military spheres.

Arthur R. Kroeber's China's Economy: What Everyone Needs to Know examines China's transformation in the 20th and 21st centuries and the country's current position in the global economy. Kroeber discusses past reforms, the long-term economic and social development that has transpired in recent decades and future problems the authorities and society will face in coming years.

Keywords: China's economy and society, reforms of China's economy, China and the world, global challenges for China. 